\title{
Methodology for the detection of accidents in the company based on the Bird pyramid
}

\section{Metodología para la detección de accidentes en la empresa con base en la pirámide de Bird}

CARPINTEYRO-CHAVEZ, Lina Mariana†*, ZAMUDIO-RODRÍGUEZ, Alexandra Berenice, BALDERAS-LÓPEZ Silvia María and TEON-VEJA, Argelia

ID $1^{\text {st }}$ Author: Lina Mariana, Carpinteyro-Chavez

ID $1^{\text {st }}$ Coauthor: Alexandra Berenice, Zamudio-Rodríguez

ID $2^{\text {nd }}$ Coauthor: Silvia María, Balderas-López

ID $3^{\text {rd }}$ Coauthor: Argelia, Teon-Veja

DOI: $10.35429 / J L D E .2020 .6 .4 .16 .21$

Received January 15, 2020; Accepted June 30, 2020

\begin{abstract}
Accidents at work are a very important issue within companies, because they reflect losses not only economic or raw material, but can affect the lives of workers, therefore it is important to develop a Methodology for the detection of accidents that allows the control of accident investigations. To carry out this project, it was necessary to carry out three phases, the first of which was research, in which technical and regulatory information sources applicable to the program were reviewed. In the second stage, the accident investigation process was designed, in which variables such as: investigation time, communication time, personnel and accident investigation follow-up were considered. Finally, a pilot run was carried out to identify the areas of opportunity of the program and define the corrective actions. Through the detection, management and control of accidents, it is possible to decrease the accident rate, this methodology identifies the root cause of the problem and generates corrective or preventive actions to avoid repeating said accident.
\end{abstract}

\begin{abstract}
Resumen
Los accidentes de trabajo son un tema muy importante dentro de las empresas, debido a que reflejan pérdidas no solo económicas o de materia prima, sino que pueden llegar a afectar la vida de los trabajadores, por ello importante desarrollar una metodología para la detección de accidentes que permita el control de las investigaciones de accidentes. Para realizar este proyecto fue necesario ejecutar tres fases, la primera de ellas la de investigación, en la cual se revisaron fuentes de información técnicas y normativas aplicables al programa. En la segunda etapa se diseñó el proceso de investigación de accidentes, en el cual se consideraron variables como: el tiempo de investigación, tiempo de la comunicación, personal y el seguimiento de investigación de los accidentes. Por último, se realizó una corrida piloto para identificar las áreas de oportunidad del programa y definir las acciones correctivas. A través de la detección el manejo y control de los accidentes, es posible disminuir la tasa de accidentes, esta metodología identifica la causa raíz del problema y genera acciones correctivas o preventivas para no repetir dicho accidente.
\end{abstract}

Metodología, Detección, Accidentes 


\section{Introduction}

Occupational accidents are organic injuries suffered by workers in their working hours, which are caused by unsafe acts and / or unsafe conditions within work facilities. In Mexico, during 2016, there were 516 thousand 734 work accidents and, on the way,, 12 thousand 622 people became ill due to the work they do at their jobs and one thousand 408 died while performing their work or as a result of it. (Prida, 2017).

The International Labor Organization estimates that every 15 seconds, a worker dies from work-related accidents or illnesses and 153 workers have an occupational accident. Every day 6,300 people die from work-related accidents or illnesses, this is more than 2 million deaths per year. (Prida, 2017). The cost of this daily adversity is enormous, and the economic burden of poor health and safety practices is estimated at four percent of global Gross Domestic Product each year.

Accident investigation is an analytical technique, which aims to discover the root cause of accidents and indicators of incidents that have occurred within the work facilities to obtain safe areas. From the knowledge of the causes, preventive and corrective measures are designed and applied to guarantee the non-repetition of the accident, for which the data and analysis of the accidents are a very important tool for the development of prevention policies and economic development. for the industry, also generating a decrease in accidents that are generated during working hours.

\section{Problematic}

The health, well-being and safety of workers and work are closely linked within this social sphere, since work is an important part of people's lives, and therefore what affects work will have a full impact on the worker health or safety. Work can have a negative impact on the health and safety of the worker when it is not carried out in safe conditions for the worker or in an unhealthy environment.

\section{Objective}

Develop the methodology for the prevention of accidents that allows the control of accident investigations for the company.

\section{Justification}

An accident investigation program enables the detection of unsafe conditions and unsafe acts in the workplace. Likewise, it continuously monitors the corrective and preventive actions that may be needed. On the other hand, this methodology makes it possible for the departments of the organization to be involved in order to identify the risks that can be generated by failures or omissions in the production processes or to verify the optimal safety conditions of the machinery or work facilities.

\section{Methodology}

The proposed accident investigation methodology was based on the Accidental Pyramid Theory, also known as the Bird's Pyramid, which was developed by Frank Bird Jr. and Frank Fernández, in which it indicates that, for every 600 incidents, there are 30 minor injuries, to occur 10 serious injuries which can present 1 tragic accident either due to the generation of days of incapacity for the worker or, in some cases, death. Based on this theory, three stages were proposed for the adaptation of the methodology.

In the first stage, investigation, a review of the information sources was carried out to define the applicable information of the accident investigation methodology, such as legal and regulatory framework, causes of accidents in the work areas and study of applicable processes for the study of accidents.

In the planning phase, the accident investigation procedure was integrated, which included the process of investigation times, upward communication times, investigation personnel, and a format was established for the accident investigation follow-up.

During execution, the information gathered from accident investigations was reviewed to determine the guidelines for the establishment of the methodology and program areas.

\section{Results}

To carry out the accident investigation, a methodology based on the Bird's Pyramid was developed, in order to determine the root cause of the accident and avoid its repetition. 
To start with the methodology, the subtopic to be placed must be determined, such as: the nature of the incident, the immediate causes, the affected parts of the body, the systematic deficiencies, the absolute safety, the type of incident, the unsafe conditions, safe star and the sources of the incident. Each one is described below:

Nature of the Incident: It refers to the damage suffered by the worker; a cut, bump, including but not limited to: cut, scratch, puncture, splinter / Bruise, contusion, pinch, crush / Sprain, strain, pull, tear / Burn, freeze / Fracture, dislocation / amputation, electric shock / Difficulty breathing, bite , sting, paralysis / Sunstroke, exhaustion loss of consciousness / Dermatitis, absorption, ingestion, inhalation / Hearing loss / foreign body / Others).

Immediate Causes: It is the cause for which the incident was generated, in this section it refers to the unsafe act that contributed to the accident (No use of PPE / No blocking, noncompliance with the globally harmonized system (SGA) / No inspection / Individual use of tools / low influence of medications / hand placement / Overexertion / Mechanical parts, Lack of rotation of activities, inadequate approach, Poor performance of the activity, poor cleaning)

Parts of the body affected: Part or area of the body of the person affected in the accident. (head, face, neck, mouth, teeth, nose, eyes, ears / Upper extremities, clavicle, shoulder, arm, elbow / Hands, wrists, palms, fingers, nails / Trunk: chest, stomach, side, pelvis, ribs, groin / Internal organs: heart, lung, kidney, liver, pancreas, other internal injuries).

Systematic Deficiencies: Systematic deficiency which contributed to the accident. The systemic deficiency refers to the administrative process in which it has various reasons, for example, poor training, it is the system deficiencies which need to be reinforced or improved, even change. (Design and engineering / Inspection or maintenance / Change management / Policies / PPE / Selection, placement / Training or entertainment / Research / Performance management / Design work)
Security Absolutes: Violation of security absolutes, which contribute to the applicable security policy in the company (1. Refusing to apply a security padlock on equipment, violating established equipment securing procedures. 2. Removing, Disabling or Avoid any safety device 3 . Refuse to follow the confined space work permit procedures when entering a confined space 4. Refuse to follow established procedures for fall protection from working at heights 5 . Introduce any part of the body in moving equipment in violation of established procedures for safe operation 6 . Operating a vehicle in an irresponsible, intimidating or threatening manner 7. Putting oneself or another person in serious danger).

Incident Type: Type of accident that was generated if the worker was hit by, trapped, or inhaled a certain chemical. (Struck by or against / caught in between / Repetitive motion / Slipping / Pushing / Pulling / Reaching / Lifting / Inhaling chemicals / Exposure to high temperatures)

Unsafe Conditions: Unsafe condition which contributed to the accident. (Defective materials / Defective equipment / Defective tools / Slippery surfaces / Poor ventilation / incorrect position)

Safe Star: Detected states and critical errors which identify worker states which contributed to the accident. (Haste / Frustration / Fatigue / Complacency) and those of critical error detected (Eyes not on the task / Mind Not on the task / Line of fire / Loss of balancetraction-grip)

Incident Sources: Incident source referring to machinery, tools and equipment. (Printing equipment / Cutting equipment / Gluing-sealing equipment / Forklifts, cranes, vehicles / Extrusion equipment / Chemicals / stairs steps / floors, walkways, ramps / Particles in the air / Doors, structures / Machine shop equipment / Storage equipment / waste equipment / contractors equipment / Falling objects / Electrical equipment / Cartoning machine / Office equipment / other machines) 
A flow chart was created which will help the responses to be concise and contain everything necessary to find the root cause and determine preventive actions which will ensure the non-repetition or aggravation of the incident.

Likewise, a question guide was created for the use of the flow chart in order to see all the sides of the accident and do not leave without reviewing any variant for which the accident arose, in order to try to have accident-free areas.

For the second part of the accident investigation methodology, it is necessary to describe the injury and the first treatment that the worker was given, referring to the first aid that was given to the worker at the time of the accident. For this, it is necessary to identify the aspects that are listed below:

The injury and treatment will be placed as specifically as possible. Do not overdiagnose, do not say "sprain" if this was treated by a first helper and the only fact is that the ankle is twisted, clearly describe the injury of the casualty. Treatment: of the state as specifically as possible, only that of first aid provided by the work facilities. The doctor's statements must be attached to the original.

The investigator must verify compliance with BBP (Control Plan for Exposure to Bloodborne Pathogens at Work and Access to Medical and Employee Exposure Records). Name of the list of involved first responders and name of the list of medical providers, including facilities and physicians.

Subsequently, the incident should be described as concisely as possible, determining: - Facts of the state that lead to the incident. . Activity what the employee was doing. - What happened. Statement of causal factors.

Regarding the immediate causes which contributed to the accident, these must be clearly and precisely described and must contain at least: - Enumeration and explanation of all unsafe conditions · Enumeration and explanation of all risk behaviors. - These should line up with the data on the front of the shape. All systematic causes found in the accident investigation should be listed. They must be clearly and precisely described and contain at least: - Enumeration and explanation of behavior and unsafe condition that has existed as well as Systemic cause.
Using the 5 why methodology, which consists of describing specifically how the accident arose and asking why 5 times, the root cause of the accident can be determined. Afterwards, the corrective actions will be placed to prevent said accident from happening again, identifying the action, the person responsible for executing said action, the commitment date and the current date. It is worth mentioning that no action should last more than 15 open days and if it turns out, preventive measures must be granted to avoid the accident.

With regard to disciplinary action, these must be indicated according to what the organization defines. To do this, it is advisable to define a plan of disciplinary recommendations on safety, which must be given to all workers to sign upon entry to work. As part of the investigation evidence, photos of evidence of the accident, equipment, machine tools, etc. will be placed. who is involved in the accident.

Finally, the people who carried out the investigation need to sign the accident investigation and the fraud alert policy, this in case the operator and the company deliver different versions at the time of the accident.

This format was created with the aim of carrying out a complete accident investigation which will not leave any, direction of the investigation or facts which may happen again said accident.

Once this methodology was proposed, a pilot test was carried out in the company to know the effectiveness in probable scenarios. For the purposes of this article, fictitious data was used to respect the company's confidentiality policy. The company has a database to record the accident investigation (See table 1). This matrix generates the statistics of the incidents, for example, the severity of the incidents, this information is used to integrate the pyramid of accidents and identify the level of risk in which the company is. 


\begin{tabular}{|l|l|l|l|l|}
\hline \multicolumn{1}{|c|}{ Date } & Department & \multicolumn{1}{c|}{$\begin{array}{c}\text { Type of } \\
\text { Violation }\end{array}$} & \multicolumn{1}{|c|}{$\begin{array}{c}\text { Body } \\
\text { Part } \\
\text { Affected }\end{array}$} & \multicolumn{1}{|c|}{$\begin{array}{c}\text { Description } \\
\text { of the } \\
\text { incident }\end{array}$} \\
\hline February & Warehouse & $\begin{array}{l}\text { Railing hit / } \\
\text { lack of } \\
\text { arrangement }\end{array}$ & Abdomen & $\begin{array}{l}\text { Edge in the } \\
\text { warehouse } \\
\text { door }\end{array}$ \\
\hline March & Corrugated & Lack of PPE & Right arm & Roller burn \\
\hline April & Warehouse & Absolute 6 & Back & $\begin{array}{l}\text { Column } \\
\text { collision }\end{array}$ \\
\hline April & Mtto & Lack of PPE & Pinkie & $\begin{array}{l}\text { Cutting by } \\
\text { placing } \\
\text { guillotine } \\
\text { knives }\end{array}$ \\
\hline April & Glued & $\begin{array}{l}\text { Unsafe } \\
\text { condition }\end{array}$ & arms & $\begin{array}{l}\text { Cuts on the } \\
\text { arms }\end{array}$ \\
\hline April & Corrugated & Lack of PPE & Right arm & Roller burn \\
\hline May & Iobox (Ladder) & $\begin{array}{l}\text { Unsafe } \\
\text { condition }\end{array}$ & $\begin{array}{l}\text { Back / } \\
\text { hands / } \\
\text { head }\end{array}$ & $\begin{array}{l}\text { Rail missing on } \\
\text { laminate stairs }\end{array}$ \\
\hline
\end{tabular}

Table 1 Database for the recording of accident analysis Source: Own elaboration

In this graph you can see how incidents and near-incidents accumulate during the year, which provides the information to know in which step of the accident pyramid.

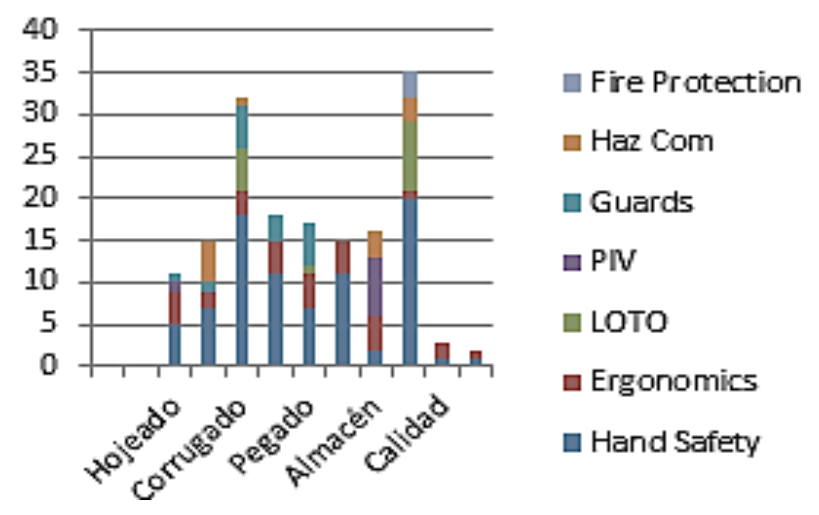

Graphic Incidents / accidents by area Source: Own elaboration

In addition to having the accumulated of all near-misses, incidents, first aid, downtime accidents or a recordable accident, the number of incidents by areas in which the focus area for the reduction of accidents can be determined.

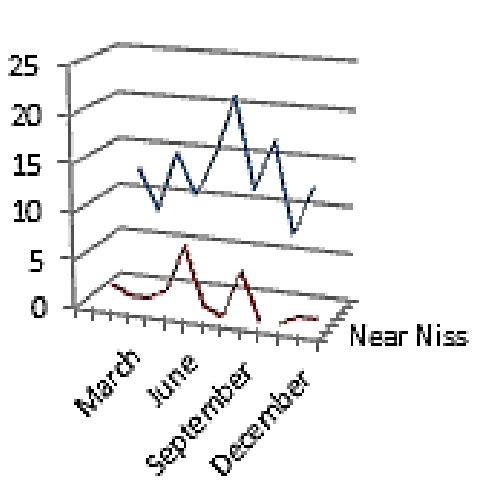

$\square$ Near Niss
$\square$ Incident
$\square$ First Aid
$\square$ Lost time
incident
$\square$ Registable
incident
$\square$ Totalmensual

Graphic 2 Incident / accident severity by area Source: Own elaboration
Statistically, it can be observed that the highest risk area is maintenance and corrugatedsheet, and among the most recurrent concepts in accidents it is in the hands, which indicates that the safety system in hands is inefficient because they are identified various areas of opportunity for improvement to avoid generating incidents and not generating a major accident.

But it is not only necessary to carry out the accident investigation in concentrate, which determines areas of focus and reasons for the accidents, for which it is chosen to use the risk mitigation program in which it consists and based on our investigation in the which provides root causes of the accident and indicates that corrective or preventive actions should be generated which are to ensure the mitigation or elimination of said risk (See figure 1).

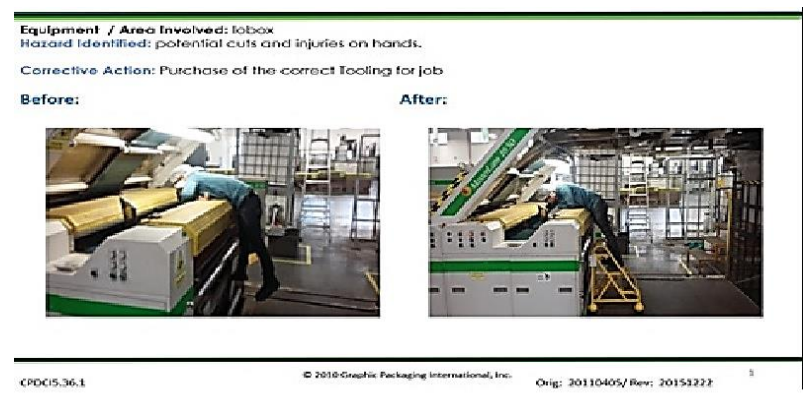

Figure 1 Corrective actions. Source: Own elaboration

Based on the information we have with the accident investigation, the area of risk mitigation is briefly placed, the before and after are shown in which it allowed us to observe how the risk was mitigated or eliminated. This is done with the aim of preventing a near miss from being skipped and potentially causing a recordable accident. In addition to the application of the methodology, the active participation of the collaborators was essential, so training was developed to publicize the procedure, in addition to the strategic placement of dissemination material.

Finally, the pilot application was validated through the comparison of the indicators generated in previous years without methodology with respect to the results obtained. 


\section{Conclusions}

The proposed objective was achieved, the accident investigation methodology proposal. Several accident investigation methodologies were used in order to do only one which would lead to the result of identifying the root cause of an accident and thus being able to mitigate all those dangers for the workers. Likewise, the importance of reporting work incidents and nearincidents was confirmed in order to detect risk areas which could generate an accident.

\section{Acknowledgments}

To Graphic Packaging International Tijuana for supporting this project.

\section{References}

Contador, P. M. (2002). La prevención de riesgos en la ley de accidentes del trabajo. Obtenido de books?id=ViElF1OOUnYC\&pg=PA120\&dq=a ccidentes+de+trabajo\&hl=es\&sa=X\&ved=0ah UKEwjpx9r7hYnmAhVPY6wKHRsuDegQ6A EIRDAE\#v=onepage $\& \mathrm{q}=$ accidentes $\% 20 \mathrm{de} \% 20$ trabajo\&f=false

Echeverría, J. A. (25 de Octubre de 2007). Investigación de accidentes y análisis de fallas de barreras preventivas. Obtenido dehttps://www.redalyc.org/articulo.oa?id=3291 27753005

España, F. e. (s.f.). Guía Interactiva de Investigación de Accidentes Laborales. Obtenido de https://contenidos.ceoe.es/CEOE/var/pool/pdf/p ublications_docs-file-229-guia-interactiva-deinvestigacion-de-accidentes-laborales.pdf

España, G. d. (08 de Noviembre de 1995). Ley de Prevención de Riesgos Laborales.Obtenido de https://www.boe.es/buscar/act.php?id=BOEA-1995-24292

Flores, W. (Marzo de 2017). Metodologia de la investigación. Obtenido de MINISTERIO DE TRABAJO Y PREVISIÓN SOCIAL: https://www.salud.gob.sv/archivos/pdf/segurida d_ocupacional_2017_presentaciones/presentaci on06042017/METODOLOGIA-DE-

INVESTIGACION-DE-ACCIDENTESLABORALES.pdf
FORUM. (2012). Análisis de la seguridad laboral mediante la medición de los niveles de estrés laboral. Obtenido de https://www.redalyc.org/articulo.oa?id=631255 63003

Ministerio de trabajo, m. y. (2018). Estadísticas de accidentes de trabajo 2018. Gobierno de España.

OIT. (2012). Registro y notificación de accidentes del trabajo y enfermedades. Obtenido de https://books.google.com/books?id=Fhi9tjmEIF 4C\&pg=PA8\&dq=accidentes + de + trabajo \&hl $=e$ s\&sa=X\&ved=0ahUKEwjpx9r7hYnmAhVPY6 wKHRsuDegQ6AEIKTAA\#v=onepage \&q=acc identes $\% 20 \mathrm{de} \% 20$ trabajo\&f=false

Portela, V. M. (18 de Diciembre de 2016). Prevención de riesgos laborales. Obtenido de https://books.google.com/books?id=KRCz6Ay MtbcC\&pg=PA6\&dq=accidentes+laboral\&hl= es\&sa $=$ X\&ved=0ahUKe

Rodríguez, F. R. (Octubre de 2010). Accidentes de trabajo, Rehabilitación emocional. Obtenido de https://books.google.com/books?id=vHAwgrU2z8C\&pg=PA43\&dq=accidentes+laboral \& $\mathrm{hl}=\mathrm{es} \& \mathrm{sa}=\mathrm{X} \& \mathrm{ved}=0 \mathrm{ahUKEwjMxq}-\mathrm{ral} \& \mathrm{f}=$ false

Rodríguez, F. R. (Octubre de 2010). Accidentes de trabajo, Rehabilitación emocional. Obtenido de https://books.google.com/books?id=vHAwgrU2z8C\&pg=PA43\&dq=accidentes+laboral\& $\mathrm{hl}=\mathrm{es} \& \mathrm{sa}=\mathrm{X} \& \mathrm{ved}=0$ ahUKEwjMxq-ral\&f=false

Valdés, J. M. (22 de Abril de 2019). Procedimiento de investigación de casos de enfermedades profesionales. Obtenido de http://www.archivosdeprevencion.com/view_do cument.php?tpd=2\&i=13801. 